\title{
Hitherto Unknown Technology of Bronze Age Inlay
}

\section{Nino Kebuladze, Nino Kalandadze}

Georgian National Museum, 3 Rustaveli Ave., 0105, Tbilisi, Georgia

nino.kebuladze@yahoo.com ninokalo@gmail.com

DOI: https://doi.org/10.52147/2667-9353/2021-1-32-50

Abstract. Daggers discovered at Tserovani cemetery of the Bronze Age - prominent specimens of decorative-applied art selected for the new exhibition of the Museum of Archaeology of the State Museum-Reserve of Greater Mtskheta - were submitted to the restoration-research laboratory of archaeological and ethnographic objects of S. Janashia Museum of Georgia of the Georgian National Museum because of repeated corrosion in some areas.

Dagger N7232 is composed and its handle is abundantly incrusted with vitreous mass. Most of the incrustation is produced with the method of melting vitreous mass inside a metal cutting. A strange exception is white circular inlay against blue background situated in three triangular cuttings. One of incrustations is damaged. The remnants were found in the cut of damaged incrustation were the vitreous mass and small grey, tubular rods made of $94 \%$ tin and $4 \%$ copper alloy (pewter) fitted in a wooden remnant.

Research allowed us to interpret presumable methods and prominence of producing incrustation: white glass embedded in circular silver partitions against the background of blue glass.

The analyses showed that the dagger was made from the typical for the late bronze period alloy-tin bronze. The artefacts, with all signs of historical development (technology, decoration methods, and ornamental motives) belong to the Colchian culture and can date in frame of this culture.

Based on the presently available data it can be stated that we are dealing with a completely new technology unknown up to present and that it can be regarded as predecessor of the cloisonne incrustation.

Keywords: Cloisonne inlay, vitreous mass, bronze, Late Bronze Age, Colchian culture

Introduction. In Georgia, two major institutions that are responsible for protecting cultural heritage - National Agency for Cultural Heritage Preservation of Georgia and Georgian National Museum - cooperate in various directions, including that of restoration-conservation of movable cultural properties. The restoration-research laboratory of archaeological and ethnographic material of S.Janashia Museum of Georgia of the Georgian National Museum is intensively involved in the process of preparing artifacts made from various alloys of archaeological metal and arranging an exhibition in the new building of the Greater Mtskheta Museum of the National Agency for Cultural Heritage Preservation of Georgia. Some of these items have never been restored before, while others bear trace of repeated corrosion.

In August 2012, in expectation of a new building, the artifacts belonging to the Greater Mtskheta Museum were temporarily housed in another building in which modes of temperature and humidity are rather inconstant. Regular relative humidity between $57 \%$ and $65 \%$ rises to $72 \%$ in wet weather. Changeable environmental conditions and presence of carbon dioxide gas, ammonia and chlorine in the air, as expected, turned out to be the source of repeated corrosion on part of earlier cleaned artifacts during high humidity periods (4:127). A group of artifacts was selected among the material in question, which was transferred from Mtskheta to the laboratory for restoration-conservation and investigation.

Our attention was drawn by one item out of 11 to be treated. It is an outstanding sample of decorative-applied art - a dagger (N7232) discovered at the Bronze-Age cemetery in Tserovani. It ended up 
on the list of artifacts to be cleaned due to the repeated corrosion revealed in places (photo 1).
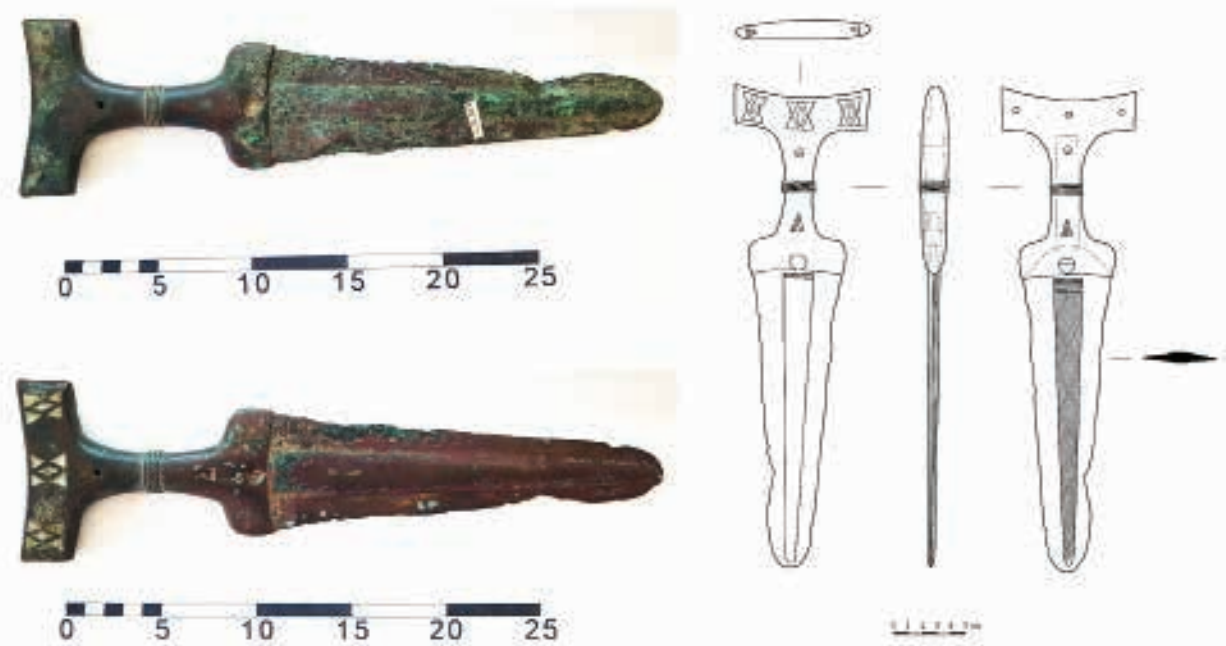

Photo 1

\section{History of the problem.}

Tserovani Cemetery II, which is situated on the lower terrace of the northern slope of the Skhaltba range (photo 2) (13:115), was researched by archaeologist Vazha Sadradze of the Tserovani Group of the Mtskheta standing archaeological expedition in 1977-1979.

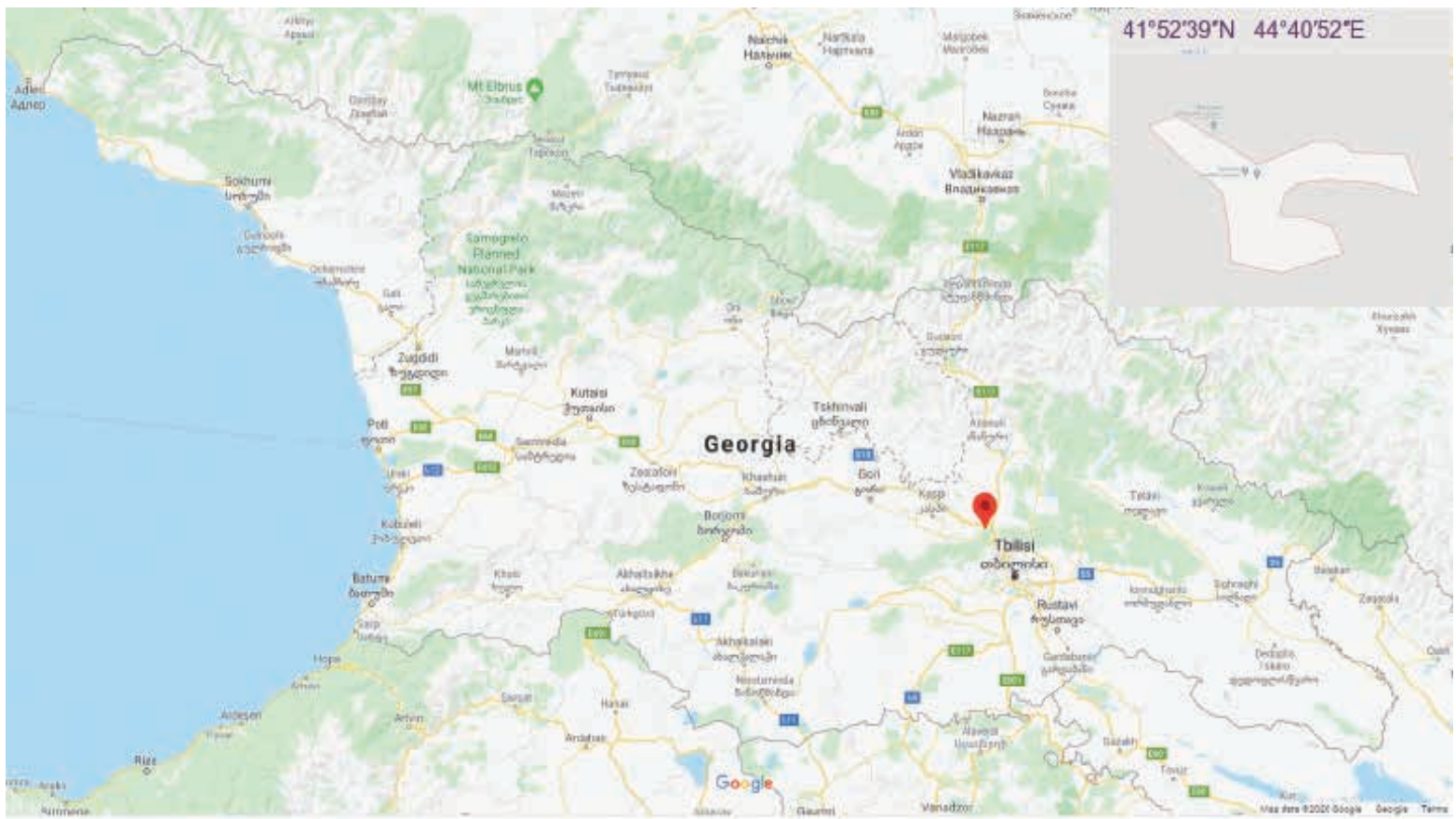

Photo 2

While working on the literature in the process of research, a damaged analog (N11220) of dagger N7232 (photo $3_{1}$ ) (tab. 13, pl. XXXVIII ${ }_{88}$ ) was found in the plates appended to the works written by the excavator of the site. The analog had been found on the territory of the same cemetery (photo $\left.3_{2}\right)(31$, pl. LXXIX $;$; 13. -PI. XXXVIII $\left.{ }_{70}\right)$. 


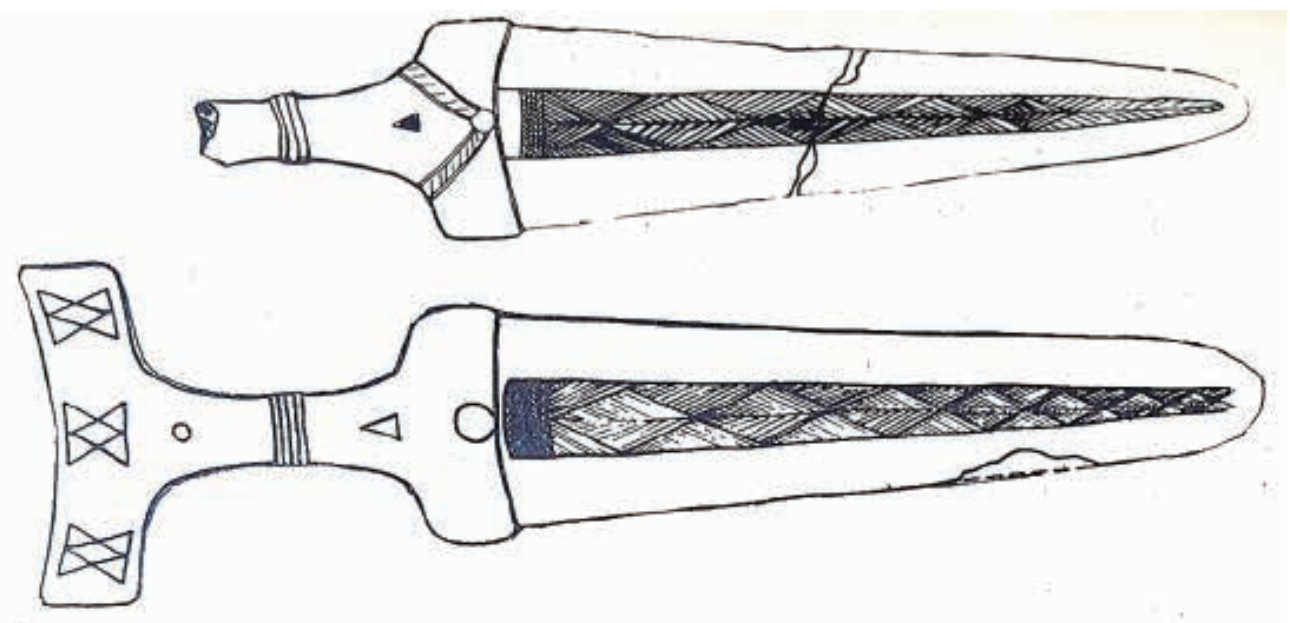

Photo 3

Finding and transferring of the dagger from the depository of the Mtskheta Museum to the laboratory was managed operatively with the help of our colleagues. Findings received during the research of the daggers proved to be complementary to the data and enabled us to restore the technology of their production.

Dagger N7232 was uncovered in grave N55 of Tserovani cemetery $\left(14^{\text {th }}-13^{\text {th }} c c\right.$ BC) in 1977 (photo $4_{2}$ ). It was an individual burial with the deceased buried on the right side in a crouching position. The dagger lay near the chest of the deceased, with its point southwards (photo $4_{3}$ ). Apart from the dagger, two more items were evidenced in the grave: head of a standard made of horn (N7231) (length $-12.3 \mathrm{~cm}$ ) and a bone ring-pendant (photo $\left.4_{1}\right)\left(31\right.$. -PI. L, -PI. LXXXI ${ }_{13}$; 11. Fig. 810-813; 11:118)

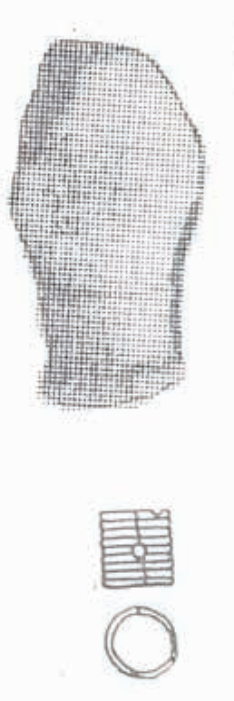

1.

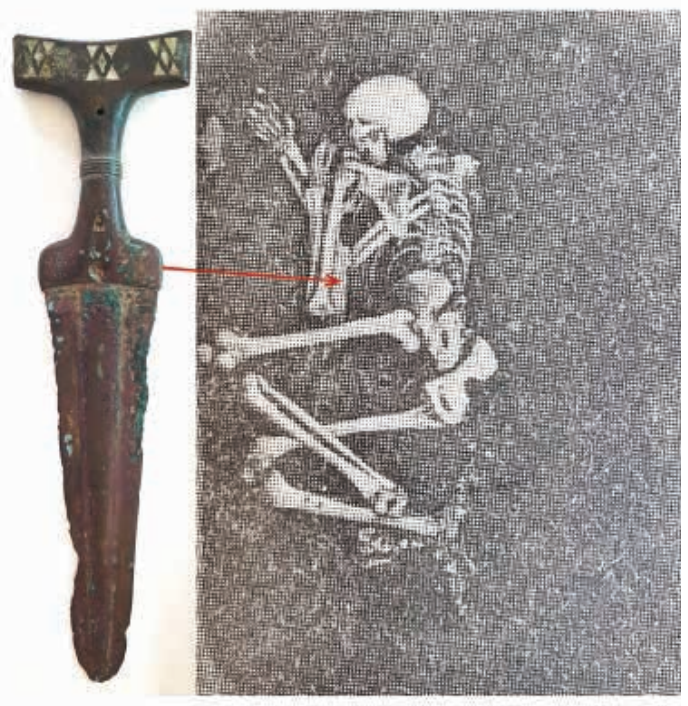

3.

Photo 4

Dagger N11220 (length $-28 \mathrm{~cm}$ ) is an accidental find. The blade of the dagger (length $-20 \mathrm{~cm}$, width $-5.8 \mathrm{~cm}$ ) and the handle are broken (photo 5). Head of the handle was not found during excavations. 

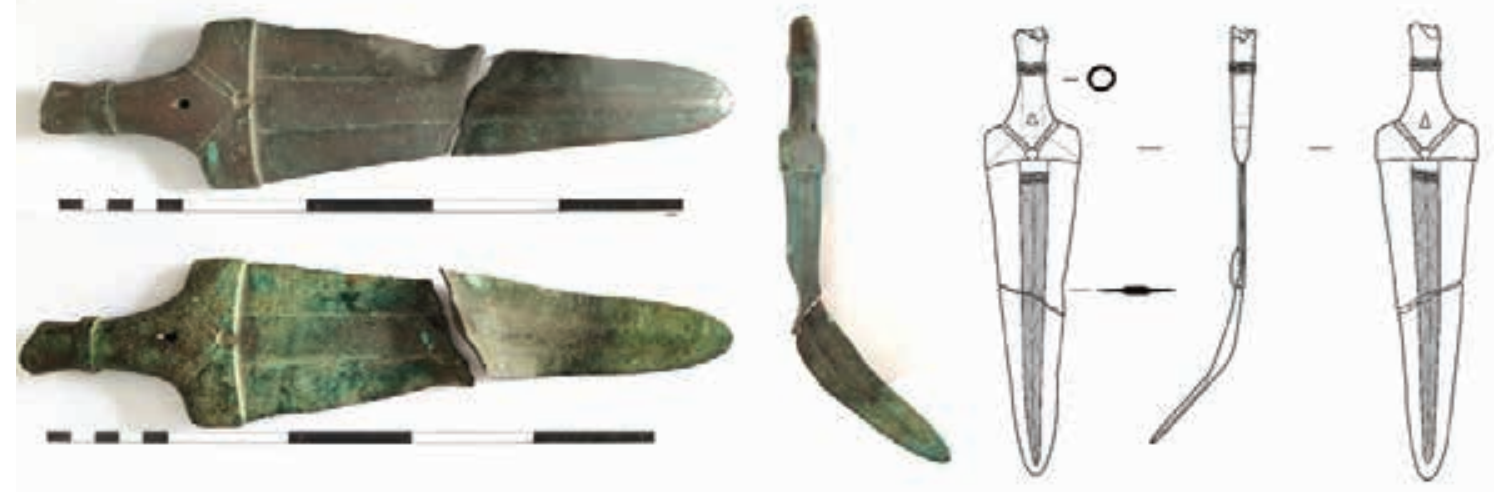

Photo 5

Before restoration, as a rule, every artifact goes through detailed examination and documentation, which involves its observation with a microscope. It was during this process that our attention was drawn by a strange incrusted detail on the dagger N7232 (for more detail see below).

In general, since their origin daggers can be considered to be exclusive specimens of fine art by the décor made in order to give them artistic looks while casting and the incrustation rendered later, which in many cases is an integral attribute.

Beside the ornamentation made while casting, handles of the daggers discovered through archaeological excavations are often decorated with rich incrustation created with silver, gold and precious stones. Metallurgists of the time already went to great lengths to give weapons artistic and attractive appearance. Apart from precious metals and stones, they used glass, wood and other materials which resulted in creating unmatched ornaments. Dagger N7232 discovered in Tserovani is one of such unique samples.

\section{Research}

\section{Macroscopic study}

The dagger is abundantly incrusted. Its length is $33 \mathrm{~cm}$, length of the handle $-12 \mathrm{~cm}$, width near the handle $-6.5 \mathrm{~cm}$ (photo 1). The dagger appeared to have been restored. Its coating and shapes are altered. Comparison of the photo taken at the moment of discovery and appended to Sadradze's work 'Bronze-Iron Age Cemetery' (11. Fig. 811) with our artifact confirmed our assumption (photo 6).

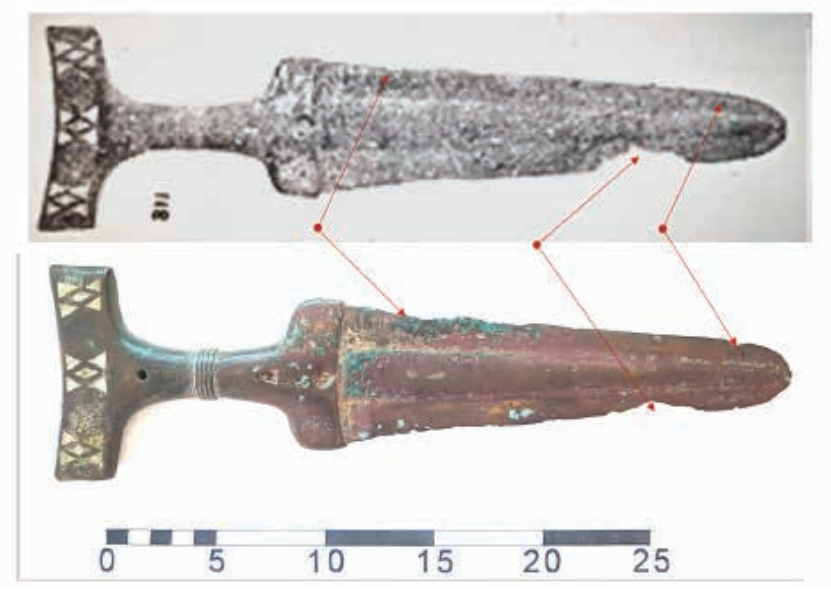

Photo 6 
We failed to find information about where and when the exhibit had been restored. As a consequence of treatment, a layer of cuprite $\left(\mathrm{Cu}_{2} \mathrm{O}\right)$, which is the primary product of slow oxidation of copper, has survived on one side of the dagger (17:433). Places of repeated corrosion are evidenced on it (photo 72 )

Beside the cuprite, surface of the other side of dagger N7232 where ornament is preserved has deposits of conversion products of copper and other metals, such as copper carbonates (copper carbonate hydroxide - malachite $\left(\mathrm{Cu}_{2} \mathrm{CO}_{3}(\mathrm{OH})_{2}\right)$ and copper chloride $(\mathrm{CuCl})$, tin oxide (cassiterite $\mathrm{SnO}_{2}$ ), etc. The engraving on the blade of the dagger is visible on this very deposit (photo $7_{1}$ ). Therefore, we did not disturb it while cleaning and only removed the chlorides. Analogous corrosive areas were found on the surface of dagger $\mathrm{N} 11220$ (photo $7_{3,4}$ )

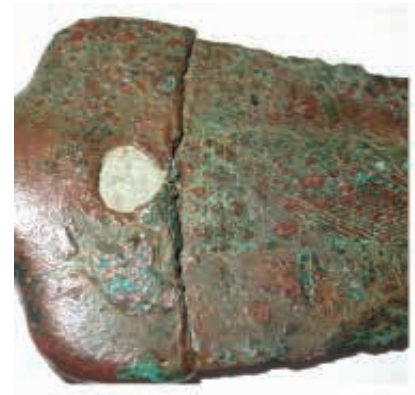

1.

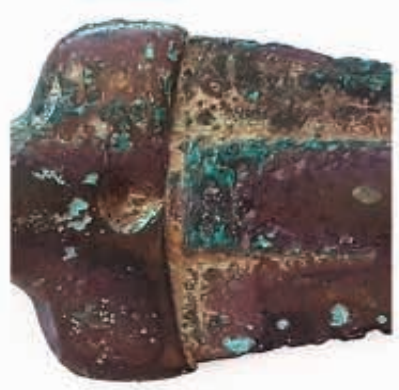

2.

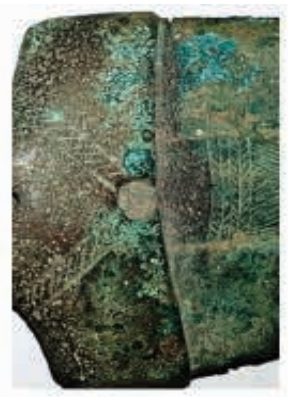

3.

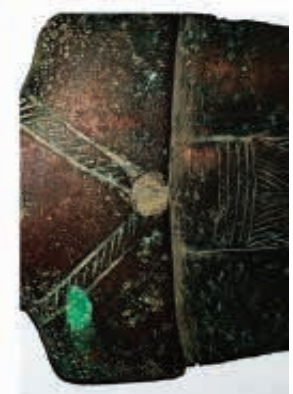

4.

Photo 7

The daggers from Tserovani are composed. In many countries bronze daggers were wholly cast, while this type of daggers of Colchian culture are composed and made with the method of casting, which is evidenced on our daggers too. This method became common in many countries later, on introducing iron. The blade of a dagger was made of iron or steel and a bronze handle or some ornamental detail was cast to it.

Damages of dagger N11220 (the blade and the handle are broken) allowed us to conceptualize the technology of producing both of the daggers. The intercepted handle of the daggers overlaps the blade. Broad, oval ridges of the blades are decorated with repeated engraved netted, rhombic ornaments on both sides which gradually narrow towards the point (photo 1 , photo 5 ). In the process of engraving, cuttings or incisions are made on the metal surface with chisels - tools made of a harder alloy than the cast item itself. For this they mainly used tools with sharp-profile heads whose basic principle is to withdraw material from the original surface by exerting force on the metal with the angle of the head of the chisel (10:58; fig. 1).

\section{Spectral study}

Analyses of the metal and the deposit of the daggers discovered at Tserovani cemetery were carried out with non-destructive X-ray fluorescence spectrometer (ElvaX), on $45 \mathrm{keV}, 100$ second live time.

The results of spectral analyses of daggers №7232 (photo $8_{1,2}$ ). and №11220 (photo $8_{3,4}$ ) are given in the form of table (see table) and logarythmic diagrams of spectra (photo 8 ). 


\section{Table}

\begin{tabular}{|c|c|c|c|c|c|c|c|c|c|c|c|c|c|c|}
\hline $\mathbf{N}$ & Name & Cu & Sn & Pb & Ag & As & Sb & Pd & Fe & Cd & Co & Ni & Ti & Zn \\
\hline 1 & Blade of dagger 7232 & 85.90 & 12.90 & 0.110 & 0.02 & - & - & - & 0.20 & 0.02 & 0.02 & 0.01 & 0.08 & 0.02 \\
\hline 2 & Handle of dagger 7232 & 79.00 & 20.00 & 1.10 & 0.09 & - & - & - & 0.07 & - & 0.01 & 0.06 & - & \\
\hline 3 & Handle of dagger 11220 & 90.783 & 0.812 & 2.468 & 0.539 & 3.640 & 1.527 & - & 0.231 & - & - & - & \\
\hline 4 & Blade of dagger 11220 & 85.635 & 9.129 & 0.297 & 0.431 & 3.910 & - & - & 0.598 & - & - & - & \\
\hline 5 & Wedge-shaped tube & 4.868 & 94,305 & - & 0,335 & - & - & 0.114 & 0.378 & - & - & - & & \\
\hline
\end{tabular}

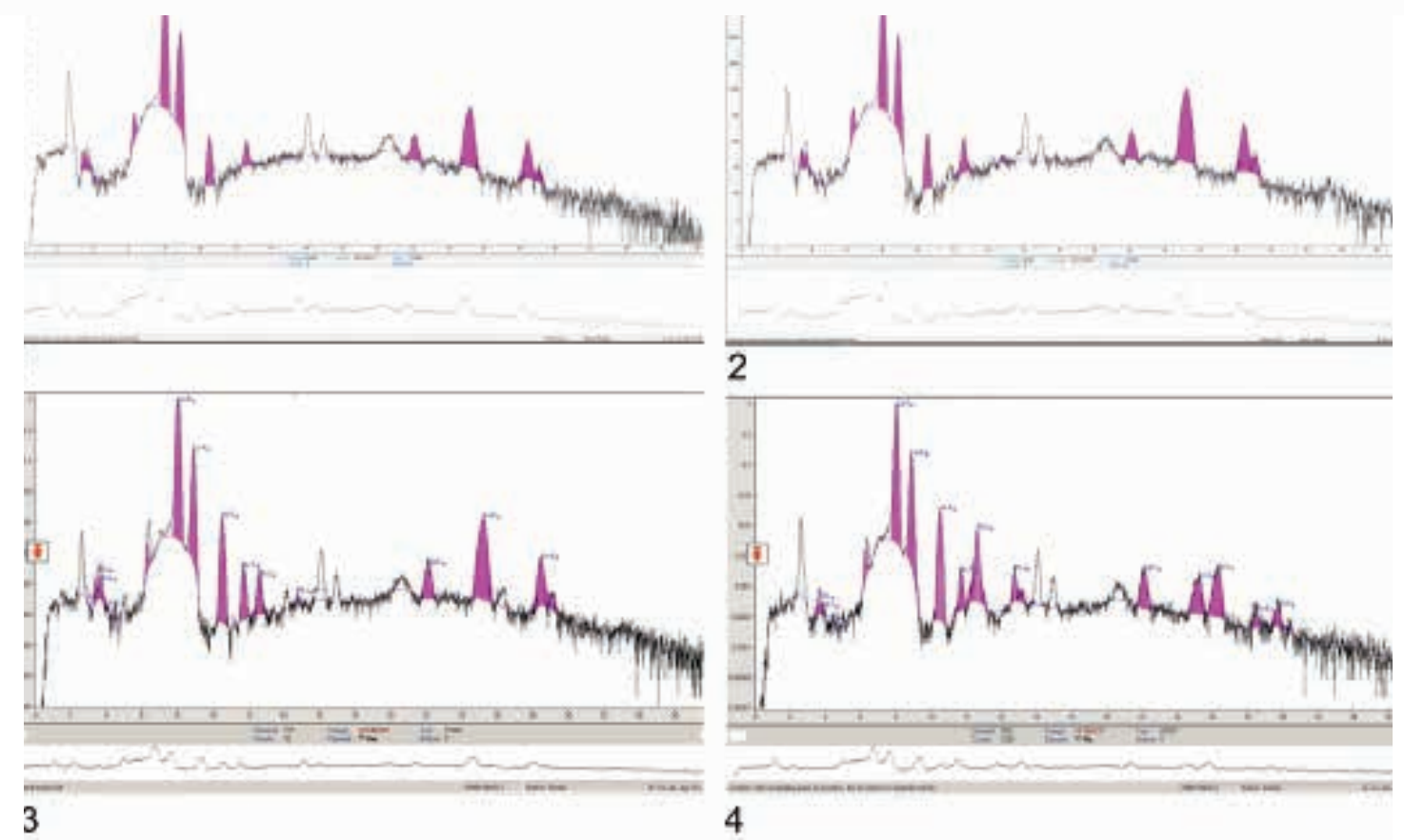

Photo 8

Analysis conducted on the blade of dagger №7232 varies up to $13 \%$ which is low compared to the handle of the same dagger, where tin as the main alloying element is in the range of $20 \%$. It is a tinned bronze alloy.

Chemical content of the handle and the blade of dagger N11220 is different: arsenic does not change ( $4 \%)$ in the alloy of both parts, while the handle exposed $\sim 5 \%$ more copper $(\mathrm{Cu})$. Proportion of antimony (Sb) in the handle is $1.527 \%$, while it is absent in the blade. There is big difference between lead and tin content. The handle contains $2.5 \%$ of lead, and the blade - only $0.297 \%$. Content of tin is reduced ten times in the handle $(\mathrm{Sn}-0.812 \%)$ compared to the blade $(9,129 \%)$.

Antimony (Sb) increases fluidity, but the alloy is still brittle and fragile. Silver (Ag) is an integral part of copper ores and, therefore, is usually found in nearly all kinds of ores (1:59).

Tin-bronze is typical of the alloys applied in the Late Bronze Age. It is characterized by high mechanic and physical features. With the rise of tin content hardness of an alloy increases, casting qualities improve and melting temperature decreases. Low coefficient of linear determination shrinkage (less than $1 \%)$ assists in receiving precise casts of elaborate décors. However, notably, high content of tin gives fragility to metal and it becomes impossible to forge $(2: 44,32: 52)$.

Tests were carried out in five different areas on the blade of dagger N11220 and it must be noted that the outcomes were very similar (difference was revealed only in a hundredth of percent), which 
indicates uniformity of the solid solution of the copper. The latter can be reached by heating the cast after casting (9:138).

Density of lead-copper alloy when it contains up to $2 \%$ of arsenic is invariable, while resistance against hitting reaches its maximum (36:77). Arsenic considerably raises hardness of lead-copper alloy, which is invariable in the case of $3 \%$ content of arsenic while it coordinately increases with further increase of arsenic (1:59). When it contains $5 \%$ arsenic, lead-copper alloy is a metal of similar qualities as tin-bronze, as arsenic creates hard compound with copper, while independent lead content remains plastic, because lead and arsenic do not produce a hard compound (36:77, 1:58).

With regard to the Late Bronze period material it has been suggested that in the cases of shortage of tin they tried to use lead. There is considerable amount of tin too in the content of the blade of the dagger from Tserovani. It is interesting why the artisan decided to substitute tin with lead. In our opinion, it was done in order to receive polychromy of the item.

The copper containing lead is difficult to cast and treat. Therefore, it is mainly used to make the kind of objects or details that do not require further treatment after being cast. Items made of leaded copper in the Late Bronze - Early Iron age are rather rarely found in Georgia (2:56).

Since ancient times the visual side and color of objects have always been important for humans (beside their function). At different stages of human development, we can even follow the peculiar "fashion" of owning items made of a particular color alloy. Such items were quite expensive and a number of legal disputes were resolved over the desire to obtain a particular item. Such facts are encountered in sources too $\left(24^{\prime} 13\right)$.

Artisans of the time achieved 'play' of colors by means of the amount of various metals, alteration of temperature and so on. All these gave certain incentive to interesting findings in the technology of metal treatment and further progress of metallurgy.

As is known, lead content of up to $5-6 \%$ does not affect the color of an alloy. Supposedly, the reason is that lead and arsenic do not form a solid compound (22:10). Consequently, an artisan retained the qualities of the alloy using lead and achieved alteration of the color of the handle and the blade of the dagger only by means of variation of the amount of tin in the alloy. Low content of antimony does not affect color of an alloy either (23:20).

The alloy of Cu-As-Sn is mainly yellow. On reaching the point of up to $5 \%$ of arsenic content the alloy of $\mathrm{Cu}$-As-Sn receives yellowish and reddish tones. By adding more than $5 \%$ of arsenic the color changes to silver. If up to $5 \%$ of tin $(\mathrm{Sn})$ is added to copper $(\mathrm{Cu})$, the red color of copper turns to pale pink. Adding $5 \%-20 \%$ of tin causes the alloy to receive a yellow tone. After going beyond this limit the yellow tone decreases. The $\mathrm{Cu}-$ alloy constitute $20-25 \% \mathrm{Sn}$ belonging to $\beta$ category of bronze is simply known as beta-bronze. This kind of bronze is characterized by light golden tones (20:11) and at $30 \%$ the alloy becomes silvery (25:117). Further cooling of the casting or its thermal treatment (forging, tempering, etc.) affects the color of an alloy. Degree of polishing can also have impact on the perception of the color.

\section{Technologycal study}

Studies showed that both daggers are made by means of lost-wax process. Moulding sand was identified inside three millimeter thickness walls of the broken cast handle of dagger N11220 and the triangular pierced hole (photo $9_{1,2}$ ). Handle of the dagger revealed composite gas holes (photo $9_{3}$ ) which generate as a result of gases produced by chemical reactions that take place during solidification-crystallization of melted metal staying in the body (7:14) and the sand core left in the socket hole 
proves that the handle of the dagger is made by means of casting in a two-valve mould using fireproof sand - core (9:138). The latter was also discovered in the circular transverse hole on the handle of dagger N7232 and the wall of the cast socket is $3 \mathrm{~mm}$ thick here too (photo $9_{4}$ ).

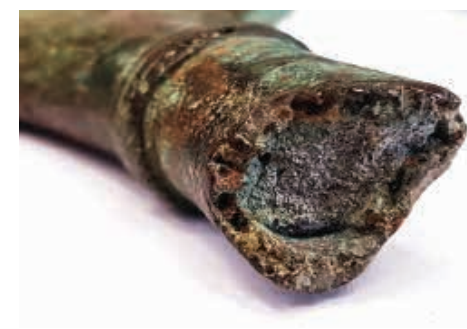

1.

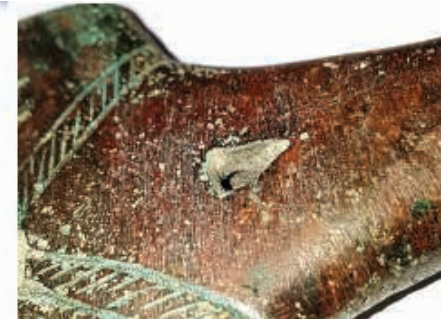

2 .

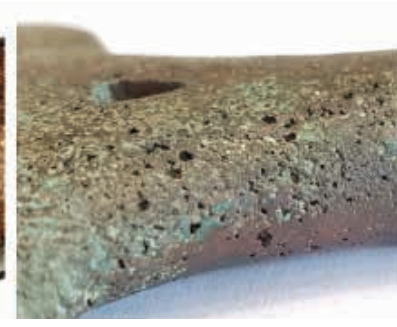

3.

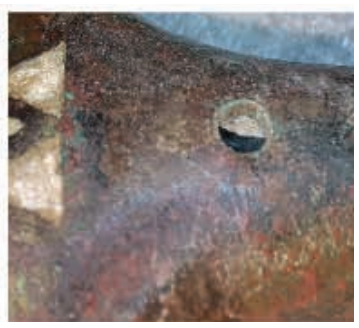

4.

Photo 9

Shank of the handle was sculpted with sand core to the blade which was made in a stone or clay mould and probably lightly forged. After the sand dried, the model of the handle was cast in wax which had every necessary detail on it. The received model was covered with moulding clay, given the shape and dried (photo 10). Afterwards, the wax was melted out of the mould and hot metal in a liquid form was poured into the red-hot mould. This would ensure that the thin walls and the shapes to be incrusted were completely filled. After the metal was solidified the artisan would open the mould and in case of any defects the cast item was treated mechanically.
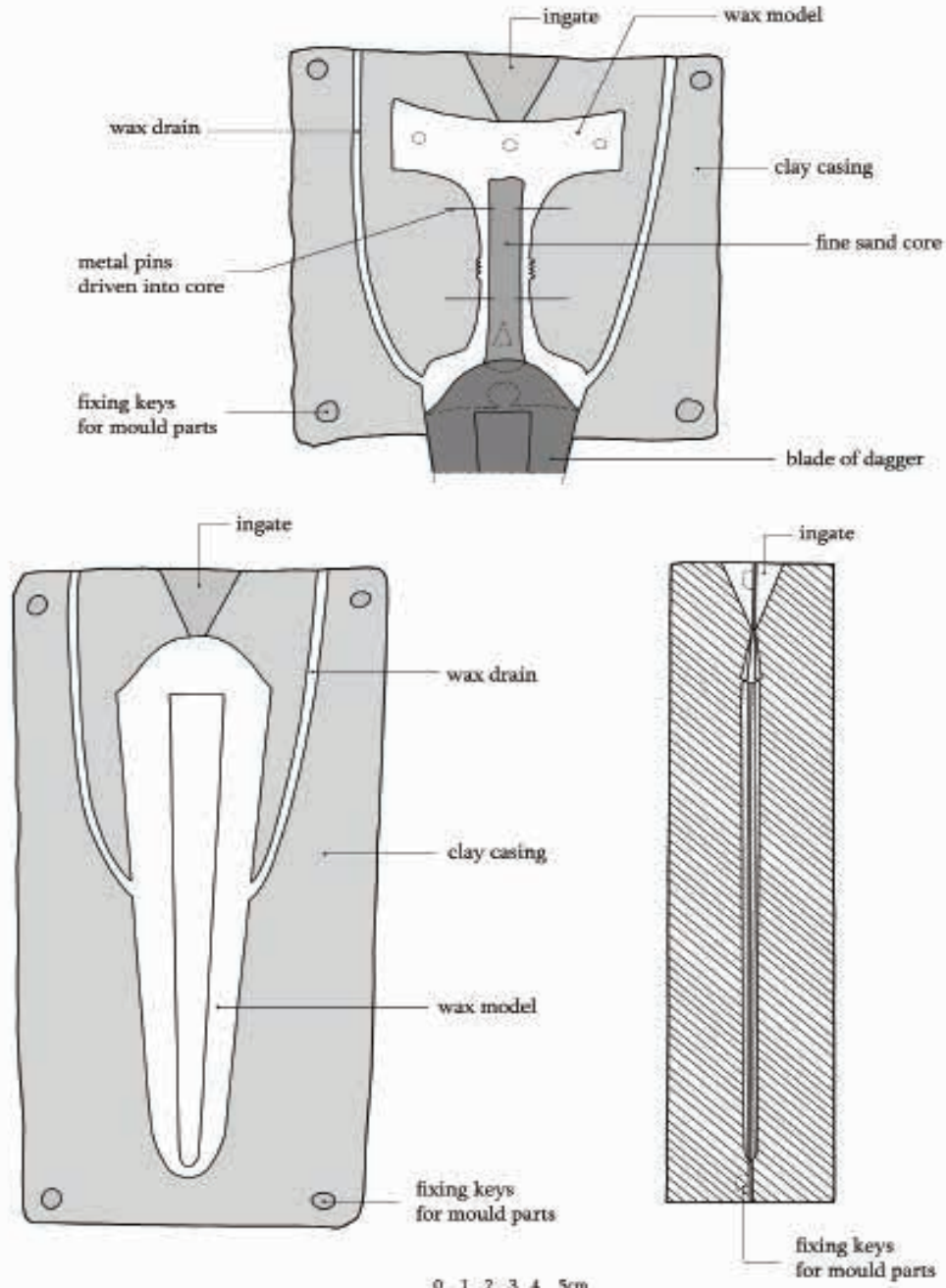

$\underbrace{0-12345} 3^{5 \mathrm{~cm}}$

Photo 10 


\section{Study of the incrustation of dagger N7232}

The handle of dagger N7232, which terminates in a curved ridge (length $-9.3 \mathrm{~cm}$, width $-1.5 \mathrm{~cm}$ ), has three circular cuttings ( $\mathrm{d}^{\sim} \mathrm{mm}$ ) on one side, at the edges of the upper part and in the middle with remains of wood (photo 11). Close examination under a microscope revealed metal as the base of the left cutting. The handle has a circular pierced hole $(\mathrm{d} \sim 5 \mathrm{~mm})$ (photo 11$)$.

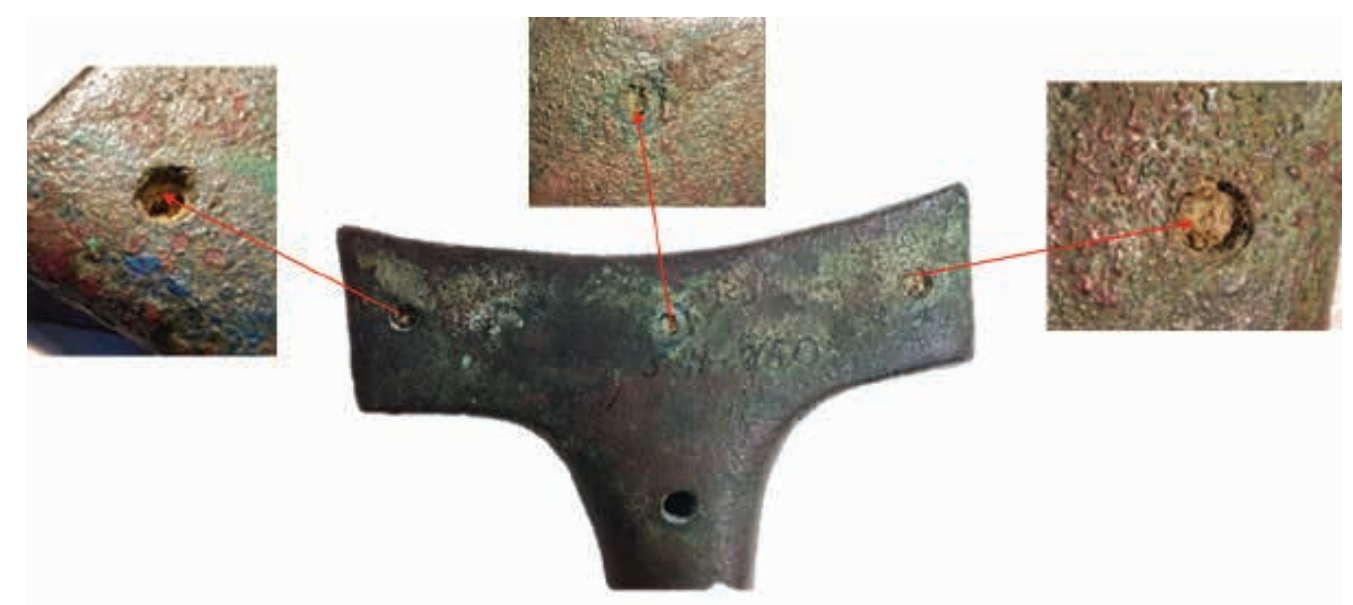

Photo 11

Central part of the handle of dagger N7232 is emphasized by a band made up of four coils (photo 1). The band of dagger N11220 consists of three coils (photo 5).

The other side of dagger N7232 is decorated with three incrustations at the edges of the upper part and in the middle. Each of them depicts four opposing triangles with a rhomb in the center. Three ornamental accents are created in this form (photo 12).

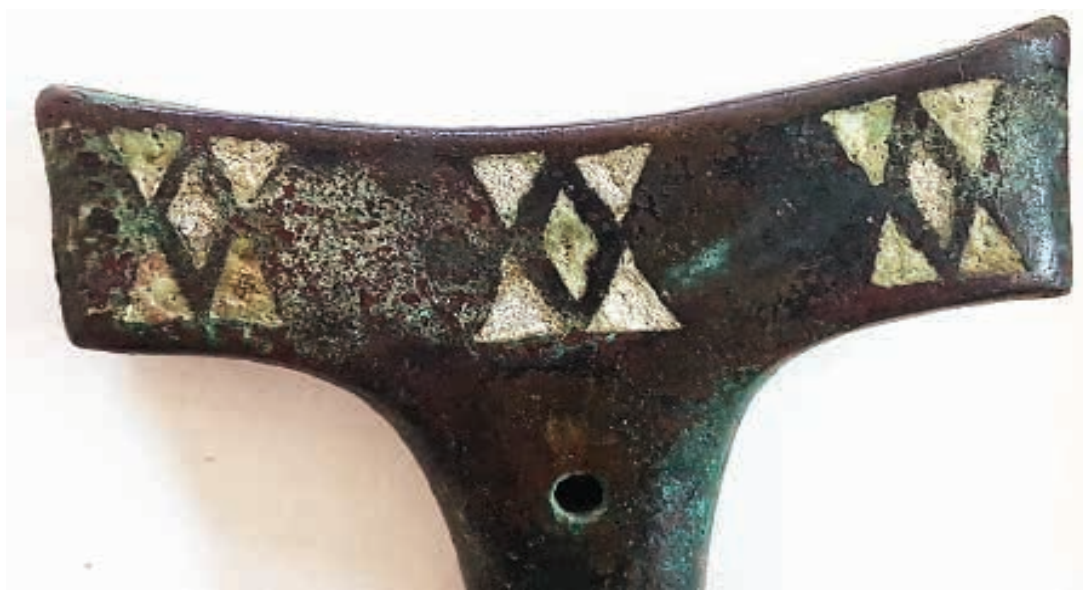

Photo 12

It is known that settings for incrustation on metal were produced with different methods. In one case cuttings were made with relevant sharp tools on smooth metal surface (20:18-21). In another, settings and holes of required shapes were carved on a wax model and the walls of the cavities of the cast workpiece were treated in a mechanic way. Glass powder was placed in the ready-made shapes 
and melted in-place. In our opinion, all the incrustation cavities and pierced circular holes on the handle of the dagger are made with the second method. The mass prepared for incrustation has almost no properties of glass.

The edges of the handle and those of the elongated oval ridge are decorated with one whitish (photo $13_{1}$ ) and one blue (photo $13_{2}$ ) triangular incrustation. Circular shapes are discerned on the blue ones (photo $13_{2}$ ), whose presumable origin will be discussed below.

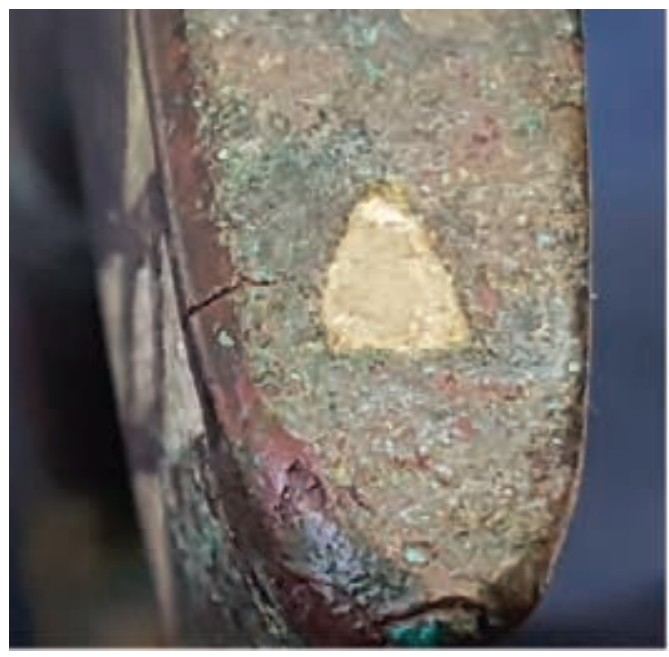

1.

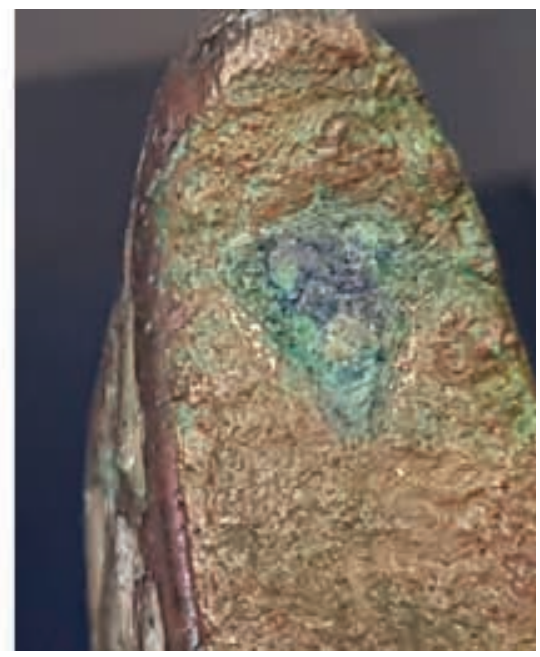

2.

Photo 13

In the case of both daggers the place where the blade meets the handle is decorated with oval cuttings in which no incrustation material is evidenced (photo 7). There is a pierced through triangular incrustation setting between the mentioned cutting and the bands in the middle of the handle (photo $14_{1,2}$ ). Regrettably, incrustations on dagger N11220 have not survived. However, this damage showed that the incrustation setting is pierced through (photo $14_{3,4}$ )

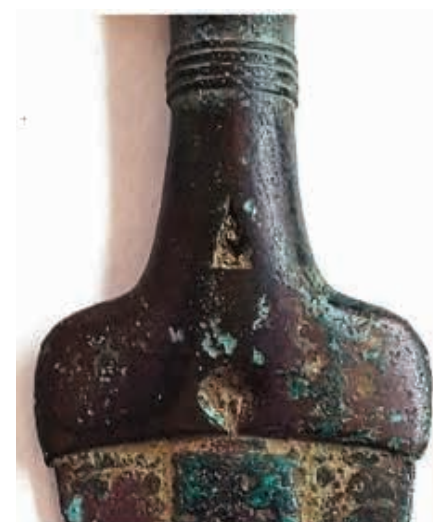

1.

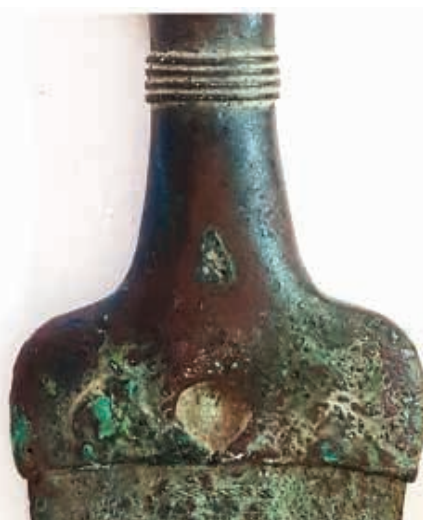

2.

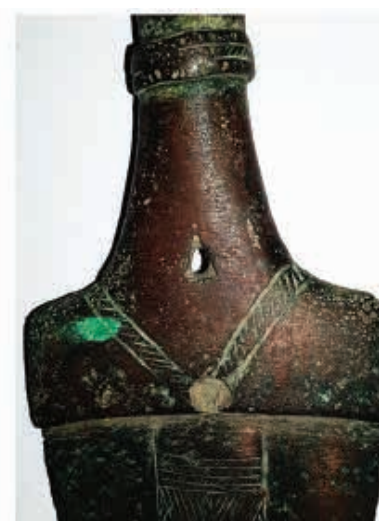

3.

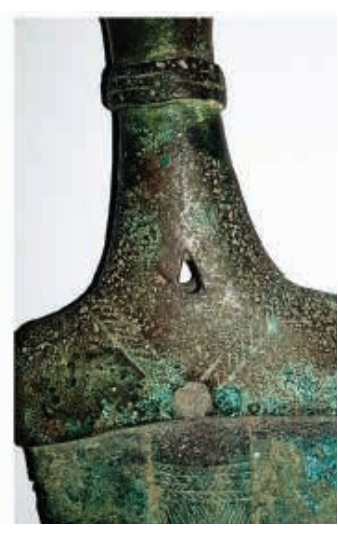

4.

Photo 14

The incrustation on the triangular cutting on one side of dagger N7232 has not survived completely. The setting yielded incrustation material which is represented by remains of vitreous mass (photo $15_{1}$ ) and grey tubular metal pins (photo $15_{3,4}$ ) fitted in wooden bed (photo $15_{1,2}$ ). 


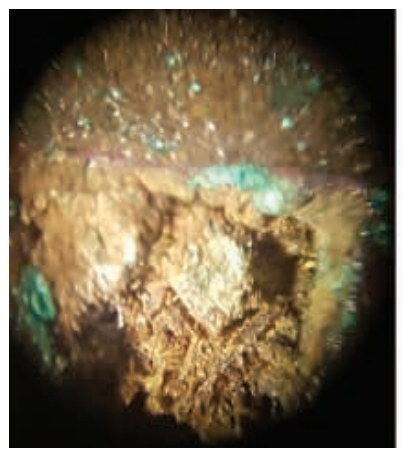

1.

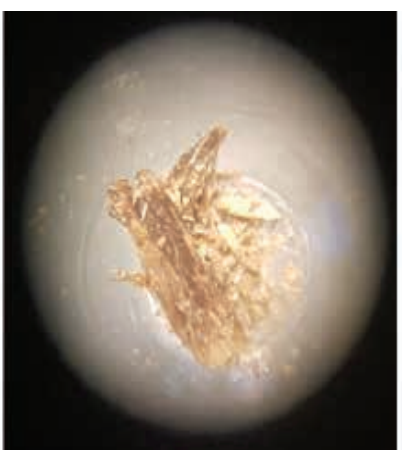

2.
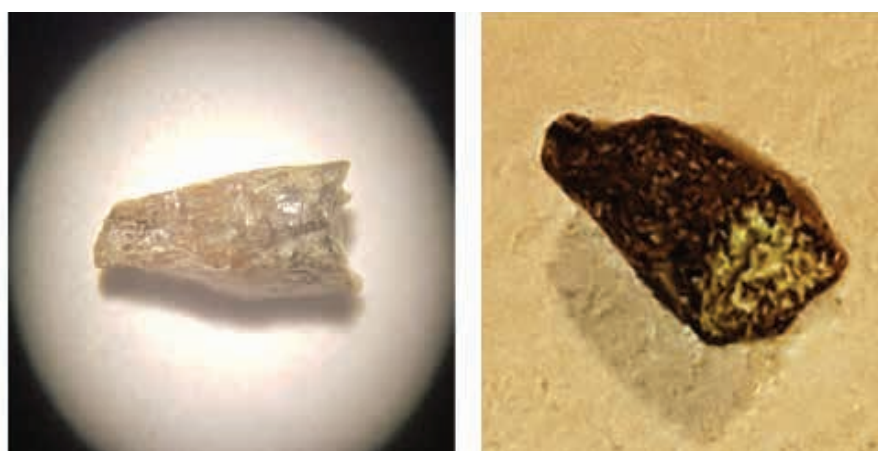

4.
3.

Photo 15

It was this damaged incrustation that drew our attention at the beginning of work and it was here that the unknown technology was documented, which is discussed further in the present article.

The metal tubes were shaken and needed conservation. It enabled us to remove one of them for analysis, place it back on completion of the study and fix it afterwards. Spectral analysis showed that the tubular pin was made of an alloy of tin and copper: $\mathrm{Sn} \sim 94 \%, \mathrm{Cu} \sim \sim \%$ (see table, test 3). This alloy is referred to as tin alloy (пьютер - in Russian, pewter - in English, hartzinn - in German) which traditionally contains $85-99 \%$ of tin and to which copper, antimony, bismuth and, sometimes, silver or lead are added.

Pale circles were evidenced on the bluish glass incrustation in one of the triangular cuttings on the other side of the dagger and the ridge (photo 14; photo 13). In our opinion, these two incrustations are made with the same technique as the damaged one.

As it was mentioned above, tubular pins in the incrustation glass are made from tin alloy whose melting point is $170^{\circ}-230^{\circ} \mathrm{C}$. Melting point of $\mathrm{SiO}_{2}$, which is the basis of glass, is very high and reaches $1700^{\circ} \mathrm{C}$. This temperature decreases by means of alkaline oxides and alkaline earth metals and oxides of various metals. Melting point of silicate glass $\left(\mathrm{SiO}_{2}+\mathrm{Na}_{2} \mathrm{O}+\mathrm{CaO}+\mathrm{MgO}+\mathrm{Al}_{2} \mathrm{O}_{3}\right)$ is $425-600^{\circ} \mathrm{C}$ is still much higher than that of the tin alloy used for making the tubes of the partitions.

Tin was used for imitating silver. Pliny recalls ancient mirrors which were produced with tin prior to using silver. Pliny's contemporaries made a tin alloy (Stanum) from tin and so-called white copper with proportion 3:1. Tin is referred to as white lead, while the lead itself is called black lead (30. 259-260).

\section{Research enabled us to identify presumable methods of incrustation:}

I - A piece of soft wood was stuck into the pierced through triangular cutting so that several millimeters were left to the surface on both sides. A mould in the shape of the cutting was prepared separately; it was filled with vitreous powder and was heated until the mass melted. Before the complete solidification of the melted vitreous mass, wedge-like small tubes filled with white vitreous mass (length 3-4 $\mathrm{mm}$ ) were driven into the melted vitreous mass; approximately $2 \mathrm{~mm}$ of their thinned ends (open) were left sticking out of the vitreous mass placed in the mould. On removing from the mould, the received incrustation detail was gradually driven into the preliminarily fitted wood with the thinned ends of the tubes by pressing on the surface (photo 16).

II - The mould was filled with vitreous mass which was melted and left to cool. The received glass sheet was perforated at a desired size in some places, stuck to the wooden piece already placed in the pierced triangular cutting of the dagger with natural glue and then specially prepared tubular tin pins filled with white vitreous mass were driven through the glass holes (photo 17). Finally, in both cases, the surface would be treated. 


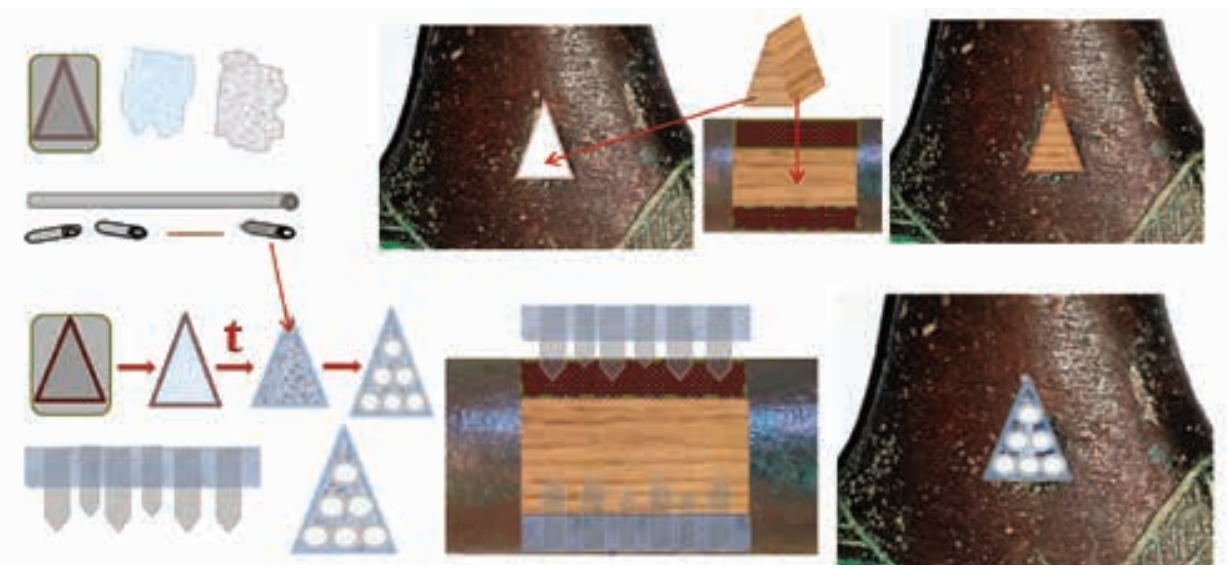

Photo 16
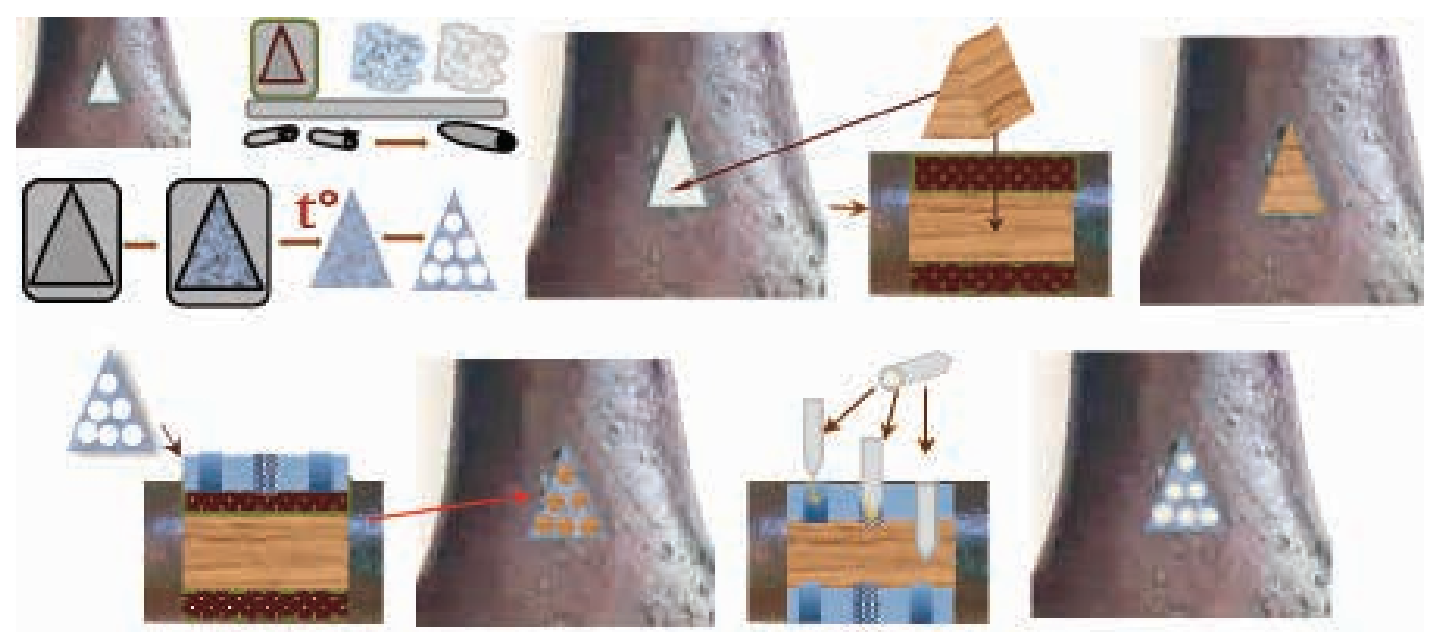

Photo 17

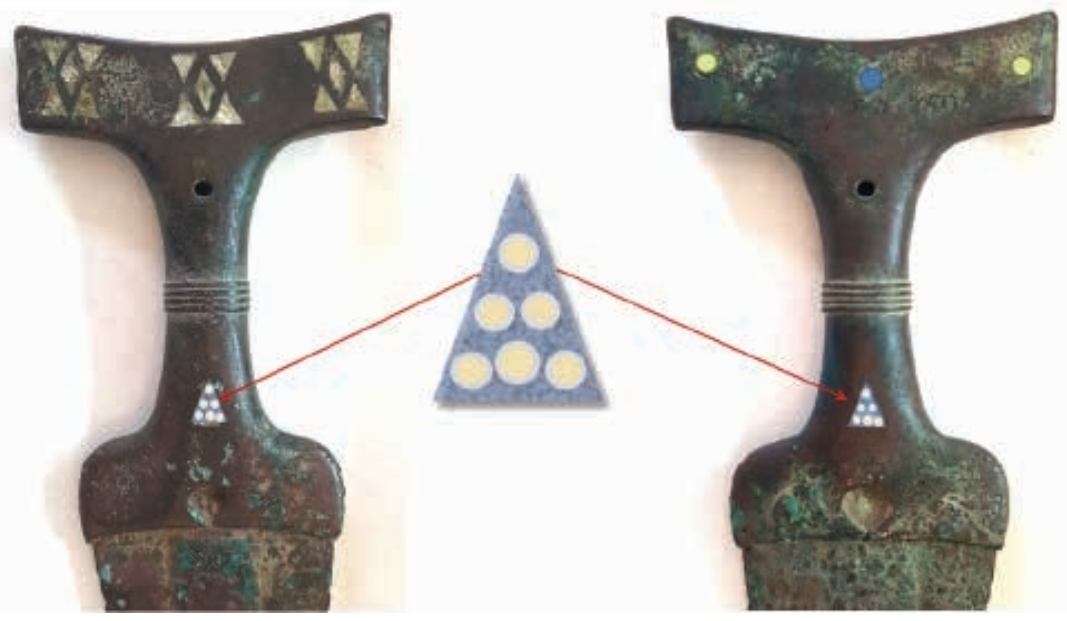

Photo 18

We did not succeed in finding artifacts with incrustation evidenced by us, or description of the technology in the photo material existing in literature or on the internet. However, in the process of search we encountered a dagger dated to the $12^{\text {th }}-10^{\text {th }}$ CC BC from Tlia cemetery (photo 18) (34:106, fig. $89_{4}$ ) whose description is similar to the artifacts discovered in Tserovani. As the author, Bagrat Tek- 
hov notes, "the handle of the dagger is very elegant and terminates in an oval curved ridge. The handle has three square cuttings filled with some mass, probably paste. Under the central square there is a pierced-through round hole. Middle part of the dagger is surrounded by a band of three coils. There is a triangular cutting a bit lower which is also filled with paste (!) (34:104). The work describes only one side of the dagger.

Fortunately, the work contained a photo of the drawing of the other side as well (Photo 19), where another triangular cutting and resemblance to the daggers from Tserovani are clearly visible (Photo $\left.19_{2,3}\right)$

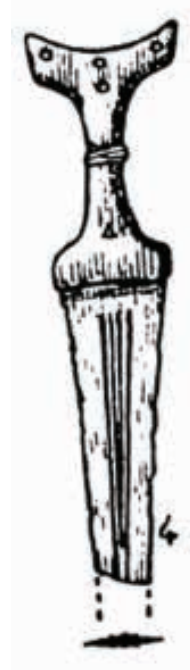

1.

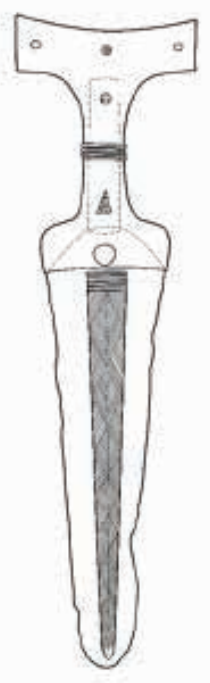

2.

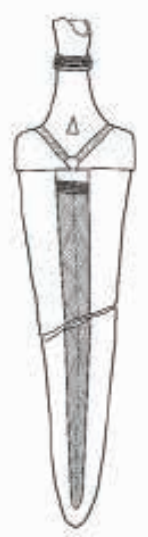

3.

Photo 19

The dagger in question has no connection with any complex and was discovered in the north-eastern part of the cemetery, where graves of the earlier stage of the Late Bronze Age had been concentrated. Tekhov failed to track down any analogies that came from more-or-less dated complexes, which is why he cannot provide the exact dates of the daggers from Tlia.

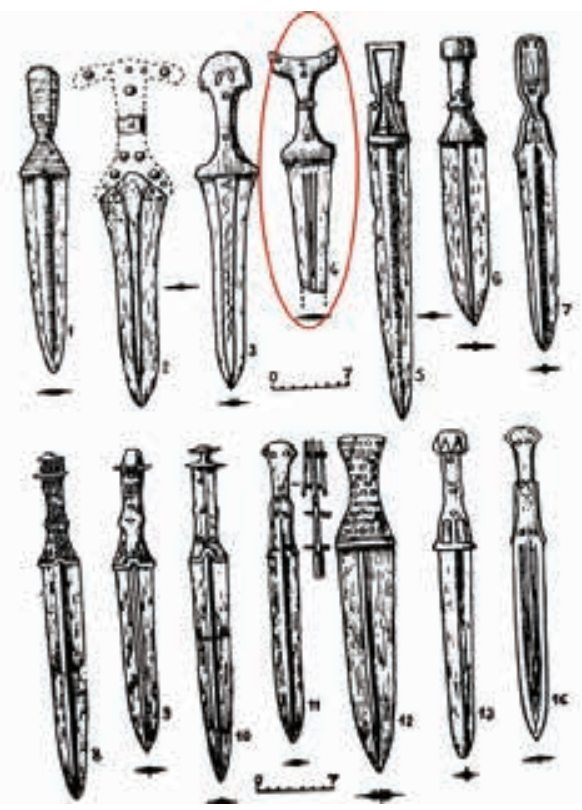

Photo 20 
The author divides daggers into nine groups. The dagger of our interest falls in group IX. According to the author, it is the technique of casting that those in group IX have in common and they are all wholly cast. They are subdivided into ten versions in terms of the shapes of their handles and blades. However, B. Tekhov notes that each of them represents individual cases (34, p. 101. Photo 20).

Bagrat Tekhov attributed the dagger of our interest to version 4. This version is completely different from others in terms of arrangement of the handle and the shape of the blade. As we see, by description the dagger looks very much like that from Tserovani. While describing the triangular incrustation, the author does not mention dots, although their presence on this sample is not excluded either, as the circular insets recorded by us had not been mentioned in the description of dagger N7232 found in Tserovani 43 years ago.

In our opinion, the analog of the daggers from Tserovani ended up in group IX by accident. By the description provided in the work, it is identical to dagger N7232 from Tserovani and probably is not wholly cast.

Presumably, this dagger is preserved in Tskhinvali museum. Unfortunately, due to objective reasons, it has been impossible to look at the dagger or track the photos. That is why we have to conduct discussion only based on the drawing and the description given in Tekhov's work.

According to Tekhov, this type of daggers is rarely found in the late Bronze Age material from Northern and Southern Caucasus. He mentions daggers from Zemo Rutkhi cemetery (central part of Northern Caucasus, the Digori Valley) (34:104) and Koban (34:104) as approximate parallels. However, we were unable to find the graphic representation brought as a parallel by Tekhov in the original work (35. PI. X, 2), which is provided by Krupnov (28:177, fig. 21,6; Photo 21 ${ }_{1}$ ) and indicated from Uvarova's book (Photo $21_{1}$ ).

In the plate (35, pl. XCIII ${ }_{19}$ ) indicated by Krupnov in Uvarova's work a different photo is registered (Photo $21_{3}$ ). We removed the dagger discovered in Koban (Photo $21_{2}$ ) from the list of the specimens of our interest due to absence of incrustation. As for the rest of the daggers, presumable presence of paste incrustation is recorded only in the description of that from Zemo Rutkhi (Photo $21_{3}$ ).

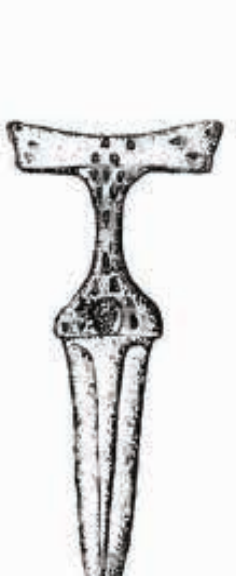

1.

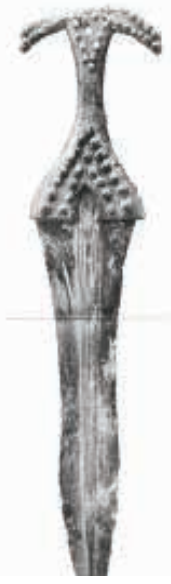

2.

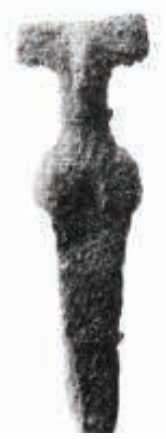

3.

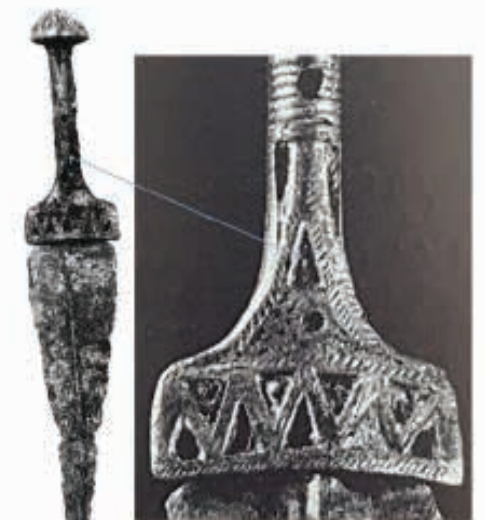

5.

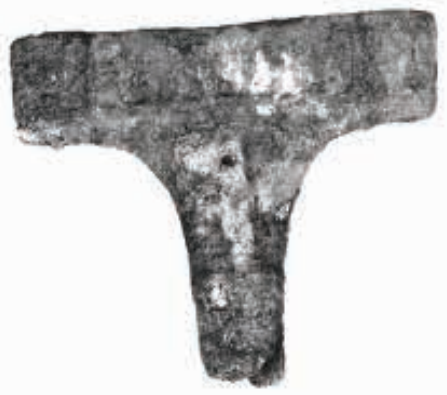

6.

Photo 21

While searching our attention was drawn by a dagger discovered during excavations of Kumbulta graves $\left(35\right.$, pl. XCVII ; photo $21_{4}$ ). Later the photo of the already cleaned dagger was published by laroslav Domanski (27, fig. 26). Three inserts can be observed in the triangular cutting made on the handle (photo $21_{5}$ ). The artifact is preserved in the Hermitage.

As it was mentioned above, the damages that dagger N11220 bears make us presume that it was 
broken deliberately. In this respect, certainly interesting is an item/fragment found on the territory of Village Chmi, $21 \mathrm{~km}$ from Vladikavkaz, which Uvarova refers to as a decorative badge or a heavy head (probably of a standard? N.K., N. K) made of cast bronze (35:115). The author notes that the artifact has a straight ridge (length $-8 \mathrm{~cm}$, width $-2 \mathrm{~cm}$ ) and a hammered band (photo $21_{6}$ ). The short description provided by Uvarova and resemblance of the item depicted on the photo with the handle of dagger N7232 suggest that the object/fragment discovered on the territory of Village Chmi is the handle top (?) Moreover, the features provided by Uvarova and photo fixation had obviously been done prior to the cleaning of the object. The dimensions given by the author are close to those of the handle of the dagger from Tserovani (length $-9.2 \mathrm{~cm}$; width $-1.6 \mathrm{~cm}$ ). In terms of technique of production and complex elements of decoration, the handle of the dagger studied by us can be considered a masterpiece of jeweler's art. It is likely that it was because of its visual aspect that they practiced secondary use of the handle as an ornament or decoration of a special object. If this assumption has the right to exist, then it will be easy to explain why dagger N11220 was broken in two and the handle was missing.

We hope that after this article is published our colleagues will contact us and provide us with further information about the incrustation existing on the specimens in question.

In terms of function, V. Sadradze divides the daggers discovered at Tserovani cemetery into two types: those for pricking/stabbing and cutting. Type I daggers are united by compound handles and resulting from diversity of shapes, they divide into two sub-types (13:137). V. Sadradze attributed the daggers of our interest to sub-type II $(13: 138$, pl. XXXV, fig. 131, 133). Like us, the author finds resemblance with the dagger from Tli; however, it should be claimed that Sadradze shares Tekhov's opinion and considers the weapons from Koban and Zemo Rutkhi as parallels too, but we do not agree with this opinion.

Part of the composite incrustation on the handle of the dagger is badly damaged which made it possible for us to examine the setting of the incrustation.

We managed to remove minor fragments $\left(1 \mathrm{~mm}^{2}\right)$ of greenish-yellowish and blue vitreous mass and conduct their spectral analysis. Qualitative test revealed microelements contained in the glass: $\mathrm{Si}, \mathrm{Ca}$, $\mathrm{Fe}, \mathrm{Cu}, \mathrm{Sr}, \mathrm{Sn}, \mathrm{Pb}$.

As is known, glass has been produced since ancient times. Archaeological excavations confirm that glass ornaments were used as early as 6000 years ago (26:92).

Silicon dioxide is glass base, which is a perfect substance for creating glass, because when melted it transitions into vitreous, or amorphic condition and impart this quality to different crystal substances - silicates (5:51).

Ancient glass is powdered quartz whose ribs are tightly joined by means of sodium and potassium which were added to levigated quartz in the form of carbonates as a melting substance and in the process of melting it converted into relevant oxides. As is known, while produce ancient glass, mainly soda or herbal sodium were employed (5; p.54). Information about using ashes in glass production is already mentioned in Babylonian chemical text dated to $1700 \mathrm{BC}$. According to Alfred Lucas sodium and potassium content in ancient glass did not exceed 1-3\% (29:288-305).

According to Pliny the Elder, in olden times there were two stages of melting glass. They melted it in kilns under permanent fire and received black lumps which were so spiked in places that one would cut oneself as deep as to the bone without feeling its touch. Then these ingots were remelted and 
colored (30:340-350).

According to periods, in order to give ancient glass various colors, they used metals of chemical elements, metal oxides and salts. For instance, in $30^{\text {th }}-6^{\text {th }}$ Cc BC on the territory of Georgia they used copper and iron oxides - $\mathrm{CuO}, \mathrm{CuO}>\mathrm{Fe}_{2} \mathrm{O}_{3}$ (light blue), $\mathrm{FeO}>\mathrm{Fe}_{2} \mathrm{O}_{3}$ (greenish blue), $\mathrm{FeO}<\mathrm{Fe}_{2} \mathrm{O}_{3}, \mathrm{CuO}+$ $\mathrm{Fe}_{2} \mathrm{O}_{3}$ (green) $(6: 87$, table 1$)$.

From the $15^{\text {th }}$ c BC there emerges glass smelted with whole glass charge: $\mathrm{Na}_{2} \mathrm{O}-\mathrm{CaO}-\mathrm{SiO}_{2}$, where $\mathrm{Na}$ reaches $15-20 \%$. This is when the use of glass colorant - metal oxides- begins.

Water is the main enemy of the glass $(6$, p. 93). However, other harm-causing substances like non-organic and organic ones can also affect archaeological glass. The degree of damage of the latter depends on its chemical content, smelting and shaping technology and duration of its presence in the soil.

Badly damaged glass can survive in the form of chalky silicon mass and it is rather hard to recognize glass in it, says Jenny Cronin (21:133). This is the case of white incrustation on the ridge of the dagger handle. As a result of impact of different factors, while leaching glass, alkalis are released from the glass content and it is covered with silicon oxide, so-calledirization layer (6:98). The samples taken by us for tests represent leached glass. It has completely lost its original form and decomposes on exerting minor force on it.

On disturbing environmental conditions, damage can develop in the museum too. For instance, when relative humidity is $\mathrm{RH}>42 \%$, unstable compounds shift towards the glass surface and create alkalic drops which, presumably, cause bad damage to the glass (21:137).

The situation is different in the triangular cuttings decorated with blue mass (photo 22). In our opinion, resulting from the production technology of these details (composition of the glass charge, applied temperature) vitreous mass turned out to be more resistant.

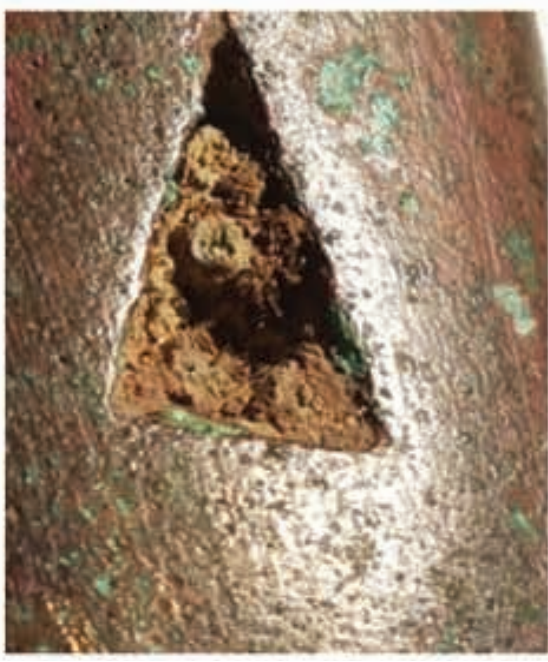

1.

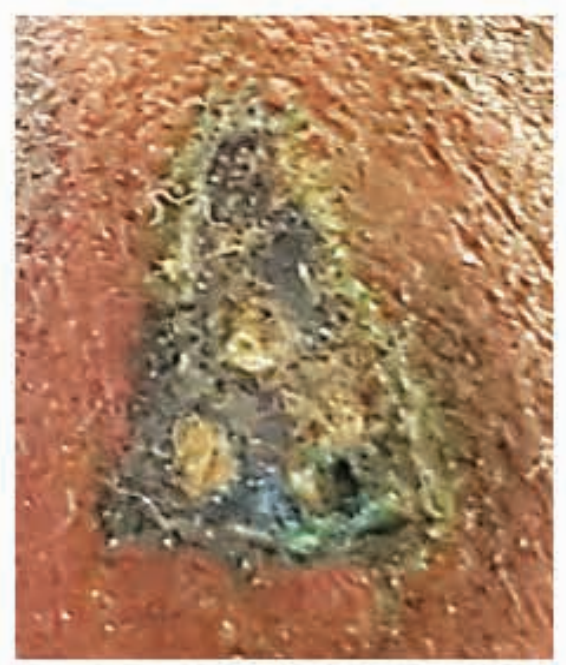

2.

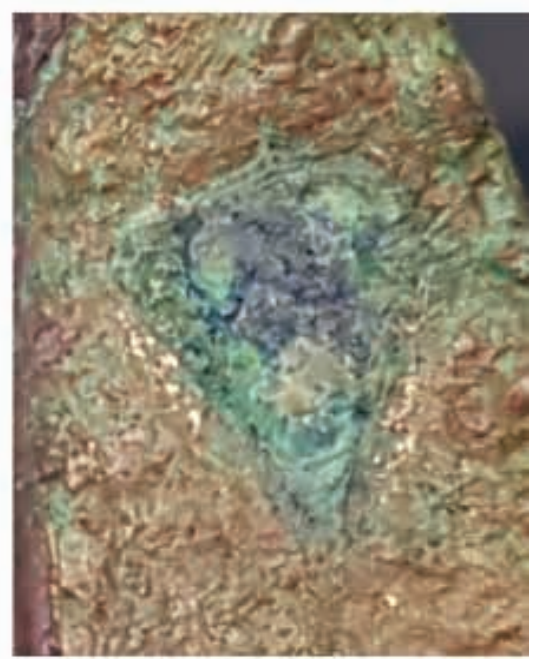

3.

Photo 22

According to some scientists, the ancient objects in which vitreous mass is used for incrustation are the buckles discovered in Caucasia (33:55).

It was estimated by $A$. Jessen that carved or engraved ornaments made on already cast objects and their incrustation with colored mass (iron, bone, wood, glass) is typical of Caucasian metallurgy during the period between the end of the II millennium BC and the beginning of the I millennium BC (10:110). 
The daggers were restored (restorer: Ana Dvali), sections of repeated corrosion were removed mechanically and both were coated with $4 \%$ acetone solution of paraloid B-72. Presently the daggers are ready to be exhibited in the new museum in Mtskheta.

\section{Conclusion}

In terms of all the features of historical development (technology, means of rendering the image, ornamental motifs), composite daggers N7232 and N11220, made by means of lost-wax process, belong to Colchian bronze and their chronological borders correspond to this culture too. It indicates that interesting incrustation produced with vitreous mass is present on the weapon from the Caucasus alongside the buckles.

Apart from the polychromy created by means of glass incrustation on dagger N7232 from Tserovani, we can evidence application of alloys of various colors on the handle and blade of dagger N11220, which is for the beauty of the object rather than for any other function. The blade of dagger N11220 would be 'warm golden' and the handle - more silvery.

As we have already mentioned, we were unable to find the incrustation made with vitreous mass fitted in wood and with metal partitions. Therefore, based on the data available presently it can be stated that we are dealing with a new, completely unknown technology that can be regarded as predecessor of the technique of cloisonne incrustation. Based on the date, the dagger investigated by us is the earliest and unique sample of incrustation produced using the technique of cloisonne.

Study is underway and we will be happy if Georgian and foreign colleagues will provide us with necessary information about the artifacts made with a similar technique, will show interest in the problem and take part in joint works.

\section{Acknowledgements}

The authors would like to express gratitude to - General director of National Agency for Cultural Heritage Preservation of Georgia Mr. Nikoloz Antidze, General Director of the Georgian National Museum, Academician David Lordkipanidze, Deputy Director of the National Agency for Cultural Heritage Preservation of Georgia, Professor Davit Lomitashvili, Director of the Greater Mtskheta Museum Mr. Nikoloz Maisurashvili, Head of the depository Ms. Eka Sokurashvili, Speicialist Ani Sherozia - for arranging uninterrupted delivery of the exhibits. Special thanks to Miss Ana Dvali, conservator of the Restoration-Research Laboratory of Archaeological and Ethnographic Objects of S.Janashia Museum of Georgia of the Georgian National Museum for the prompt restoration-conservation conducted in accordance with modern standards. Thanks to Ms, Inga Esvanjia, draftswoman, Ms.Nino Gabunia-translator and Ms. Maia Cholokashvili for cooperation. 


\section{Reference}

1. Abesadze Ts. Trialetis k'ulturis spilendz-brinjaos met'alurgiis ist'oriisatvis, samuzeumo eksponat'ta rest'avratsia, k’onservatsia, t'eknologia I, “metsniereba”, Tbilisi 1974, pp.27-77 (ed. Bakhtadze R.).

2. Abesadze Ts., Bakhtaze R., Dvali T., Japaridze O. spilendz-brinjaos metalurgiis ist'oriisatvis sakartveloshi. Tb. 1958.

3. Abesadze Ts., Bakhtaze R. k'olkhuri k'ulturis metalurgiis istoriisatvis. samuzeumo eksponat'ta rest'avratsia, k'onservatsia, teknologia IV, “metsniereba”, Tbilisi 1988, pp.3-91 (ed. Bakhtadze R.).

4. Abesadze Ts., Bakhtaze R. Mtskhetis ak'ldamashi aghmochenili brinjaos kandak'ebis aghdgena. Ak'ad.S. Janashias sakhelobis sakartvelos sakhelmts'ipo muzeumis moambe, sakartvelos metsnierebata akademiis gamomtsemloba, Tbilisi 1956. Pp.127-134 (ed.V.Kalandadze).

5. Bakhtaze R. Udzvelesi minis ts'armoebis zogierti sakitkhi. samuzeumo eksponat'ta rest'avratsia, k'onservatsia, t'eknologia III, “metsniereba”, Tbilisi 1977, pp.51-91 (ed. Bakhtadze R.).

6. Bakhtaze R., Sarajishvili N. Arkeologiuri minis gamopit'vis p'roduct'ebis shests'avla da op't'imaluri konservant'is shercheva. samuzeumo eksponat'ta rest'avratsia, k'onservatsia, teknologia IV, "metsniereba", Tbilisi 1988, pp.92-107 (ed. R. Bakht'adze).

7. Tavadze P., Sakvarelidze T. sakartveloshi arkeologiuri gatkhrebit nap'ovni spilendzis da brinjaos naketobata damzadebis t'eknologiis aghdgenistvis. Metsniereba da t'eknik'a. metsnierul-p'op'ularuli zhurnali \#5, saqartvelos metsnierebata ak'ademia. Tbilisi 1950.

8. Tavadze P., Sakvarelidze T. Dzveli kartuli brinjaos satevrebisa da makhvilebis chamoskhma da damushaveba. sak.ssr.metsn. ak'ademiis litonisa da samto kimiis inst'it'ut'is shromebi. v.VII. 1956 pp.349-360.

9. Tavadze P., Sakvarelidze T., Dvali T. T. Tbilisis midamoebshi aghmochenili brinjaos nivtebis damzadebis t'eknologia. Ak'ad.S.Janashias sakhelobis sakartvelos sakhelmts'ipo muzeumis moambe XVII-A. 1956. Pp.135-142 (ed. V.Kalandadze).

10. Kalandadze N. kolkhetis gvianbrijao-adrerk'inis khanis gravirebuli da ink'rust'irebuli brinjaos nats'armi (t'ipologiur-t'eknologiuri gamok'vleva). ist'oriis metsnirebata k'andidat'is khariskhis mosap'oveblad ts'armodgenili disertvacia (khelnats'eris uflebit). 2006.

11. Sadradze V. brinjao-rkinis khanis samarovani. Mtskheta, arkeologiuri k'leva-dziebis shedegebi, v.IX.1989 pp.77-154.

12. Sadradze V. Mtskhetis zv.w'. II-I atasts'leulis p'irvel nakhevarshi (shida kartlis dzeglebis kronologia-p'eriodizatsiis sakitxebi). avt'oreperat' $i$ ist'oriis mets'nierebata doktoris sametsniero khariskhis mosap'oveblad). Metsniereba. (khelnats'eris uplebit), sakartvelos metsnierebata ak'ademia arkeologiuri k'vlevis tsent'ri. Tbilisi. 2000.

13. Sadradze V. Mtsketis da misi shemogarenis dzv.ts'. II-I atasts'leulis p'irveli naxevris arkeologiuri dzeglebi. mets'niereba. Tbilisi 2002. sakartvelos metsnierebata ak'ademia arkeologiuri k'vlevis tsent'ri. Mtskhetis arkeologiuri inst'it'ut'i. (ed. A.Apakidze).

14. Sulava N. samtavros samarovnis pibulebiani samarkhebis datarighebisatvis. Dziebani -metsnierebata ak'ademiis arkeologiuri k'vlevis tsent'ris zhurnali \#5. Tbilisi 2000. pp.65-71 (ed. Ot. Lortkipanidze).

15. Sulava N. Kalandadze N. Minit ikrust'irebuli udzvelesi nivtebi brilis da samtavros samarovnebidan. ak'ademia, ist'oriul-pilologiuri zhurnali \#6-7, Tbilisi 2006. pp.11-16.

16. Pantskhava L., Maisuradze B., Gobejishvili G. Brilis samarovanze 1939 ts'els gatkhrili \#12 samarkhis datarighebisatvis, Dziebani-metsnierebata ak'ademiis arkeologiuri k'vlevis tsent'ris zhurnali \#8. Tbilisi 2001. pp.65-71 (ed. Ot.Lortkipanidze).

17. Kebuladze N., Dzigua N., Goginashvili N. Arkeologiuri da etnograpiuli sp'ilendzis shenadnobebis k'vleva da restavratsia-k'onservatsiis metodebis shedarebiti analizi. sakartvelos erovnuli muzeumis moambe VII(52-B), Tbilisi 2016. pp.429-451 XVII-A. 
18. Koridze D. k'olkhuri k'ult'uris ist'oriisatvis. Tbilisi 1965. p. 111.

19. Javakhishvili Al, Chubinishvili T. Udis gandzi, sabch'ota khelovneba, \#4. Tbilisi 1959. pp. 59-64.

20. Born, H.: Meisterwerke kaukasischer Bronzeschmiede, Bilderhefte der SMPK Berlin, no. 47, 1984, pp. 1821).

21. Cronyn J.M. The Elements of Archaeological Conservation. 2004.

22. Mecking $\mathrm{O}$. The colours of archaeological copper alloys in binary and ternary copper alloys with varying amounts of Pb, Sn and Zn. Journal of Archaeological Science, 121 (2020) 1-16.

23. MÖdlinger M., Kuijpers M.H.G., Braekmans D., Berger D. Quantitative comparisons of the color of CuAs, CuSn, CuNi, and CuSb alloys. Journal of Archaeological Science 88 (2017) 14-23.

24. Plutarch Mordis, De pythise oraculis 2 (395B-D) CicceroTusculance Disputationes 4.32.

25. Radivojevi M., Pendi J., Sreji A., Kora M., Davey C., Benzonelli A., Martinon-Torres M., Jovanovi N., Kamberovi Z., Experimental design of the Cu-As-Sn ternary colour diagram. Journal of Archaeological Science 90 (2018). 106-119.

26. Golba P.U. vivetrivanie stekla, M. 1938, p. 56.

27. Domanskii la.V. drevnaia khudojestvennaia bronza kavkaza (v sobranii gosudarstvennogo ermitajha. Moscow. 1984.

28. Krupnov E.I. Drevnaia istoria severnogo kavkaza. 1960.

29. Lucas A. Materiali I remeslennie proizvodstva drevnego egipta. M.1958. pp. 288-305.

30. Gaius Plinius Secundus. Estestvennaia istoria iskopaemikh tel. S.peterburg pri imperatorskoi akademii hauk, 1819. 36. XXVI. 65, 66, 67.

31. Sadradze V.G. Mtskheta v XV-XIIIvv. do nashei eri (voprosi khronologii I periodizatsii pamiatnikov shida kartli) Tbilisi. Metsniereba 1991. Akademia nauk Gruzii. Arkheologicheskaia komisia bysnbnen bcnjhbb, arkheologii I etnograpii im. I.A.Javakhishvili. Tsentr arkheologicheskikh issledovanii (ed. A.M. Apakidze).

32. Tavadze P., Sakvarelidze T. Bronzi drevnei gruzii, academia nauk gruzinskoi sssr, institute metalla $b$ gornogo dela, izd. Academia nauk gruzinskoi ssr, Tbilisi 1959 (ed. A. I. Javakhishvili).

33. Tenisheva M. Emal I inkrustatsia. Praga 1930.

34. Tekhov B.V. tsentralnii kavkaz v XVI-X vv.do n.e. Moscow.

35. Uvarova P.S. mogilniki severnogo kavklaza. - MAK, vip.VIII, M.1900.

36. Shpagin A.I., Kalistratova G.M. spetsialnie bronzi I latuni. Gos.nauchn.tekhn.izd. po chernoi I tsvetnoi metalurgii. M 1945. 